\title{
Impact of invasive alien plant species on aquatic biodiversity of Koshi Tappu Wetlands : Ramsar Site, Nepal
}

\author{
I. P. Pandey ${ }^{1}$, D. N. Shah ${ }^{1 *}$ and R. D.Tachamo-Shah ${ }^{2}$
}

Koshi Tappu Wetlands play a significant role in the conservation of many rare and endangered species of flora and fauna. However, this wetland is threatened by several natural and anthropogenic stressors; among others, invasion by invasive species is the most serious problem. The objective of this study was to prepare an inventory list of wetlands, categorize the wetlands based on the coverage of alien species, identify the problematic aquatic invasive plant species, and assess their impact on water quality and aquatic biodiversity (fish and macroinvertebrates). This study was conducted in winter and spring seasons of 2018. Composite water samples were collected from the wetlands with different covers of invasive species. Macroinvertebrate samples were collected using hand net of $500 \mu \mathrm{m}$ mesh following the habitat specific sampling approach, and fishes were sampled using Cast Net. The analysis of water quality parameters, macroinvertebrates and fishes were performed for different levels of invasion. Altogether, 66 wetlands were documented in the Buffer Zone located in the east of eastern embankment of the KTWR. Out of the total 66 wetlands, $33.33 \%$ were found to be non-invaded while $66.67 \%$ were found to be invaded by the invasive macrophytes. The invaded wetlands were further subdivided into abundant ' $\mathrm{A}$ ' (>75\% coverage), common ' $\mathrm{C}$ ' (50-75\% coverage) frequent 'F' (25-50\%coverage), occasional 'O' (5-25\% coverage), and rare 'R' (1-5\% coverage) which were found to have occupied $19.69 \%, 16.67 \%, 12.12 \%, 13.63 \%$ and $4.50 \%$, respectively, of the invaded wetlands (66.61\%). The most problematic invasive species were found to be Eichhornia crassipes and Ipomoea carnea. The dissolved oxygen (DO) decreased while the total alkalinity and free $\mathrm{CO}_{2}$ increased significantly with the increased coverage of invasive macrophytes. The macroinvertebrate diversity was observed high in common and abundant coverage, but the fish diversity was high in the frequent coverage of invasive species. The taxa compositions shifted from "Decapoda" and "Ephemeroptera" to "Odonata" and "Mollusca" in none to abundant coverage of invasive species. The findings of this research are expected to help wetland managers and related stakeholders to understand the level of impact of different coverage of invasive species on wetlands, help to develop the conservation strategy and action plans to mitigate the spread of these invasive species, and wise use of wetlands.

Keywords: Coverage class, fish, macroinvertebrates, water quality

I nvasive Alien Species (IAS) are the species which have the capacity to compete with native species outside their geographical origin (CBD, 1992). IAS are of great concern for conservationists and natural resource managers because of their rapid spreading nature, competitiveness and capability to colonize in new areas within short time period (Rejmánek and Richardson, 1996). These species primarily gain entry into new geographic areas through human activities, environmental disturbances, deforestation and forest degradation, and forest fire which promotes the establishment of the species (Early et al., 2016; McNeely, 2001). IAS have negative consequences to native species and ecosystem services (MEA, 2005) by predation,

1 Central Department of Environmental Science, Tribhuvan University, Kirtipur, Kathmandu, Nepal. *E-mail: dnshah@cdes.edu.np

2 Aquatic Ecology Centre, Kathmandu University, Dhulikhel, Nepal. 
competition and habitat modification (McGeoch et al., 2010). Invasive species have become a threat for $42 \%$ of the native species to fall into endangerment in the United States (Pimentel et al., 2005). Freshwater ecosystems are at high risk of invasion compared to the terrestrial ecosystems as the vulnerability of invasion varies with biotic resistance of ecosystems (Rejmánek and Richardson, 1996).

Half of the world's wetlands have been lost, and the remaining are degraded due to large-scale water diversion, introduction of invasive species, overharvesting, industrial pollution and climate change (Carpenter et al., 2011). In Nepal, wetlands occupy approximately $5 \%$ of the total area of the country (DoFD, 2012). These wetlands are converting into unproductive land due to exotic plant species, expansion of cropland, siltation, overharvesting, land use change, and climate change. Out of the total 219 alien species of flowering plants (Siwakoti, 2012; Sukhorukov, 2014; Tiwari et al., 2005), 26 plant species including 6 species in wetlands are invasive in Nepal (Shrestha, 2017).

Koshi Tappu, the first Ramsar Site designated in 1987, plays a significant role in the conservation of many rare and endangered plant species together with different fishes, resident and migratory birds and mammals. However, this Ramsar Site is threatened by different array of natural and anthropogenic factors out of which invasion of alien species in aquatic and terrestrial ecosystem is a serious problem (Savillo, 2009). In aquatic ecosystem, macrophytes influence the nutrient dynamics and water quality, and finally contribute to the primary productivity which alter the fish and macro-invertebrate communities (Kovalenko et al., 2010; Petr, 2000). Macroinvertebrates have important link in the food web between decomposing leaves and algae, fish and other vertebrates, and are valuable indicators in assessments of environmental change (Shah et al., 2011; Shah et al., 2015).Tiwari et al. (2005) divided IAS in four risk categories, viz .i) very high risk, ii) high risk, iii) medium risk, and iv) low risk based on their coverage and abundance in which Eichhornia crassipes and Ipomoea carnea fall into high risk, and are recorded from the Koshi Tappu Wildlife Reserve (KTWR) and surrounding areas. Alternanthera philoxeroides and Myriophyllum aquaticum have been categorized in medium risk species while Pistia stratiotes under the category posing low risk.
E. crassipes, I. carnea, P. stratiotes and $A$. philoxeroides are native to the tropical and subtropical region (Penfound \& Earle, 1948). These species were introduced in Nepal because of their attractive flower and ornamental purpose (Tiwari et al., 2005). IAS reproduce sexually and asexually, and proliferate in short periods (Gopal, 1987; Zhu et al., 2015). These characteristics of IAS enhance the growth and coverage in the water bodies which consequently block the sunlight into water leading to changes in the water chemistry (Bassett et al., 2012; Mujere, 2016). This also reduces the space for native aquatic flora and fauna (Sharma and Bachheti, 2013). The dense mat in the aquatic body creates the mosquito and pathogen breeding-habitat (Zimmels et al., 2006) which is dangerous to spreading human diseases.

The Koshi Tappu Wetlands are covered predominately by water hyacinth (E. crassipes). The local people harvest water hyacinth for biogas production, food for pigs, fertilizer in field, and raw materials for handicraft for the conservation and sustainable use of the wetland (Maharjan \& Ming, 2012; Tiwari et al., 2005). In some areas, Ipomoea spp. is used for fencing, firewood, raw materials for paper production, green manure, flood and soil erosion control (Fatima et al., 2014). However, the management interventions, so far, are not enough; as a result, the spread of these Invasive Alien Plant Species (IAPS) is increasing over the years. This has direct negative consequences to the wetland habitats, its aquatic biodiversity and on the livelihood of the wetland dependent communities (Kovalenko et al., 2010). So far, very few studies have been conducted on the invasive species and their impacts on Koshi Tappu and other wetlands of Nepal. Therefore, the present study aims to determine the impacts of IAPS on water quality and assemblages of aquatic biodiversity in Koshi Tappu Wetlands.

\section{Materials and methods Study area}

The study was carried out in the buffer zone of the Koshi Tappu Wildlife Reserve (KTWR, Figure 1). The KTWR, having a core area of $175 \mathrm{~km}^{2}$, was established in 1976 under the National Parks and Wildlife Conservation Act. On the other hand, the KTWR Buffer Zone surrounding the reserve was declared in 2004 with an area of $173.5 \mathrm{~km}^{2}$. 
The KTWR exhibits sub-tropical type of climate with the temperature ranging between 8.3$32.3^{\circ} \mathrm{Cand}$ the annual precipitation of $2,019 \mathrm{~mm}$. The reserve is rich in biodiversity with 670 species of vascular plants (Siwakoti, 2012), 21 species of mammals (Chhetry and Pal, 2011), 45 species of herpetofauna, 494 species of birds, 77 species of butterflies (DNPWC, 2009) and 42 taxa of macroinvertebrates (Khatri et al., 2010). In Koshi Tappu, the local communities are highly dependent on wetland resources for their livelihoods (Thapa and Dahal, 2009). This wetland contributes 16 million USD from ecosystem services annually (Sharma et al., 2015). In the Koshi Tappu area, over 250 wetlands are used for fisheries. Many of these wetlands are dominated by invasive macrophytes such as E. crassipes, I. carnea, $P$. stratiotes, and A. philoxeroides.

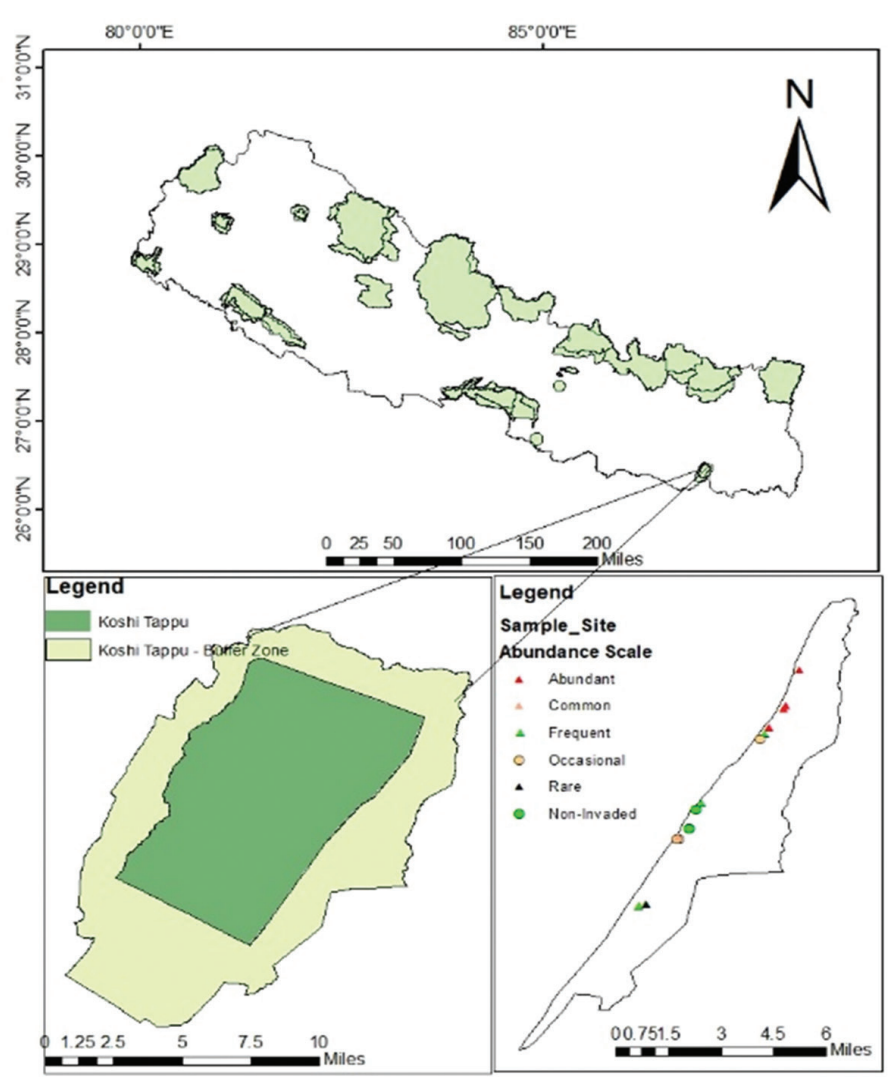

Fig. 1: Location of the KTWR in the map of Nepal and the adjacent buffer zone (bottom left) together with the distribution of sampling sites within the buffer zone situated in the easternmost embankment of the KTWR (bottom right)

\section{Methods}

The wetlands situated in the easternmost embankment of the KTWR Buffer Zone were listed visually, and were categorized based on the coverage of IAS. The coverage of the dominant macrophytes was noted, estimated visually on the basis of ACFOR abundance scale provided by Stiers et al. (2011) and no coverage wetland based on the Braun-Blanquet cover/ abundance scale. The classes were categorized as abundant ' $\mathrm{A}$ ' $(>75 \%$ coverage), common 'C' (50-75\% coverage), frequent ' $\mathrm{F}$ ' $(25-50 \%$ coverage), occasional 'O' (5-25\% coverage) and rare ' $\mathrm{R}$ ' (1-5\%). Among the listed wetlands, 12 were assessed to determine the water quality, macroinvertebrates and fish diversity across the invasive coverage classes during winter (January, 2018) and spring (May, 2018) seasons. For the water quality parameters, water samples were taken from different points representing different micro-habitats, and were mixed to make a single composite sample for the analysis from each wetland. The water $\mathrm{pH}$, temperature, total dissolved solids, conductivity and dissolved oxygen were measured instantly during sample collection using multi parameter probe (Hanna Port) and DO meter (YSI-ecosense DO, 200A), respectively. Other parameters were analyzed in the laboratory of the Central Department of Environmental Science (TU-CDES),Tribhuvan Universityusing standard methods as described in APHA (1998).

A Cast Net of $40 \mathrm{~mm}$ mesh size was used to collect the fish samples. A hand net with 500-micron mesh size was used to collect the macro-invertebrate samples following the habitat specific approach ( Tachamo-Shah et al., 2011; Shah et al., 2015). The fish specimens were identified based onShrestha (2008). Similarly, the macroinvertebrates were identified using the country specific keys (Shah et al., 2015; Nesemann et al., 2007; Nesemann et al., 2011).

\section{Data analysis}

The Sorenson's Similarity Index was used to determine the community similarity within the same coverage class while the Shannon Diversity Index and evenness were used to calculate the diversity of the macroinvertebrates and fishes. Similarly, the Kendall Rank Correlation was used to detect the correlation between the coverage 
of invasive species and water quality parameters. Likewise, the Mann-Whitney U-test was used to compare the seasonal data. On the other hand, the Analysis of Similarities (ANOSIM) was used to test the community similarity between the coverage classes; the stress value gives the level of community dissimilarity. All the analyses were done in the Rstudio1.1.423 Software, and the inventory map was prepared using the ArcGIS 10.4 Software.

\section{Results}

Inventory of wetlands

Altogether 66 wetlands were documented in the east of eastern embankment within the buffer zone of the KTWR. Based on the field observation, $33.33 \%$ wetlands were found to be without invasive macrophytes while $66.67 \%$ were found to be invaded ones which were further categorized as abundant ' $\mathrm{A}$ ' $(>75 \%$ coverage); common 'C' (50$75 \%$ coverage); frequent ' $\mathrm{F}$ ' (25-50\% coverage); occasional 'O' (5-25\% coverage), and rare

'R' (1-5\% coverage); these sub-classes were found to have occupied $19.69 \%, 16.67 \%, 12.12 \%$, $13.63 \%$ and $4.50 \%$, respectively of the invaded wetlands (66.61\%) (Figure 2).

The non-invaded wetlands $(33.33 \%)$ had regular human interference because of their fishing activities. Some of these non-invaded wetlands were near from the settlements whereas the invaded wetlands were near from the agricultural areas, consequently with less human disturbance. The less-invaded wetlands had intermediate disturbances due to human activities. Abundant coverage of invasive species was observed in the abandoned wetlands located nearby the agricultural areas.

\section{Water quality parameters}

The temperature of water, though not statistically significant, was observed to have negative relation in winter but almost no correlation in spring season (Table 1). The $\mathrm{pH}$ of water showed the negative correlation in both the seasons. The $\mathrm{pH}$ value decreased with the increasing coverage of invasive species. The $\mathrm{pH}$ value was slightly acidic in the wetlands invaded by invasive species. 
Table 1. Correlation between different coverage level of invasive macrophytes and water quality parameters in the wetlands of KTWR

\begin{tabular}{|l|l|c|c|c|c|}
\hline \multirow{2}{*}{ SN } & \multirow{2}{*}{ Parameters (unit) } & \multicolumn{2}{|c|}{ Winter } & \multicolumn{2}{c|}{ Spring } \\
\cline { 3 - 6 } & & $\begin{array}{c}\text { Concentration } \\
\text { (Mean } \pm \text { S.D. })\end{array}$ & $\begin{array}{c}\text { Correlation } \\
\text { value }\end{array}$ & $\begin{array}{c}\text { Concentration } \\
\text { (Mean } \pm \text { S.D) }\end{array}$ & $\begin{array}{c}\text { Correlation } \\
\text { value }\end{array}$ \\
\hline 1 & Temperature $(\square)$ & $18.33 \pm 1.64$ & -0.31 & $30.18 \pm 2.57$ & 0.09 \\
\hline 2 & $\mathrm{pH}$ & $7.95 \pm 0.5$ & -0.57 & $7.79 \pm 0.63$ & -0.37 \\
\hline 3 & TDS $(\mathrm{ppm})$ & $169 \pm 57.97$ & 0.07 & $115.20 \pm 24.27$ & 0.06 \\
\hline 4 & Conductivity $\left(\mu \mathrm{S} \mathrm{cm} \mathrm{cm}^{-1}\right)$ & $285 \pm 84$ & 0.57 & $225.91 \pm 49.42$ & 0.25 \\
\hline 5 & Dissolved Oxygen $(\mathrm{mg} / \mathrm{L})$ & $2.33 \pm 0.67$ & $-0.64^{*}$ & $1.14 \pm 0.23$ & $-0.77^{*}$ \\
\hline 6 & Turbidity $(\mathrm{NTU})$ & $7.48 \pm 7.005$ & -0.43 & $10.14 \pm 11.55$ & -0.28 \\
\hline 7 & Total Hardness $(\mathrm{mg} / \mathrm{L})$ & $130 \pm 40$ & 0.57 & $177.16 \pm 51.93$ & 0.15 \\
\hline 8 & Total Alkalinity $(\mathrm{mg} / \mathrm{L})$ & $211.25 \pm 46$ & $0.62^{*}$ & $57.51 \pm 15.44$ & -0.02 \\
\hline 9 & Free CO $(\mathrm{mg} / \mathrm{L})$ & $4.95 \pm 2.27$ & $0.75^{*}$ & $9.17 \pm 2.94$ & $0.55^{*}$ \\
\hline 10 & Ammonia $(\mathrm{mg} / \mathrm{L})$ & $0.20 \pm 0.02$ & 0.04 & $0.36 \pm 0.014$ & -0.25 \\
\hline 11 & Chloride $(\mathrm{mg} / \mathrm{L})$ & $3.55 \pm 2.27$ & -0.35 & $5.80 \pm 3.55$ & 0.02 \\
\hline 12 & Nitrate $(\mathrm{mg} / \mathrm{L})$ & $5.21 \pm 1.65$ & -0.11 & $2.14 \pm 0.92$ & 0.06 \\
\hline 13 & Phosphate $(\mathrm{mg} / \mathrm{L})$ & $0.18 \pm 0.05$ & 0.21 & $0.19 \pm 0.05$ & 0.18 \\
\hline 14 & Iron $(\mathrm{mg} / \mathrm{L})$ & $0.71 \pm 0.003$ & 0.40 & $0.25 \pm 0.0011$ & -0.11 \\
\hline 15 & Potassium $(\mathrm{mg} / \mathrm{L})$ & $4.04 \pm 2.8$ & -0.29 & $1.57 \pm 1.015$ & -0.05 \\
\hline 16 & Chlorophyll-a $(\mathrm{mg} / \mathrm{L})$ & $0.23 \pm 0.19$ & 0.07 & $0.98 \pm 0.52$ & -0.40 \\
\hline
\end{tabular}

*indicates significant relation at $\mathrm{p}<0.05$

The dissolved oxygen (DO) significantly decreased with the increased coverage of invasive species (Table 1) while the free carbon dioxide $\left(\mathrm{CO}_{2}\right)$ showed positive correlation with the increased coverage of macrophytes in both the seasons. The total alkalinity was found to be higher $(211.25 \pm 46 \mathrm{mg})$ in the increased coverage of invasive species during winter season, but almost no relationship was found in the spring season.

\section{Macroinvertebrate assemblages}

Altogether, 41 taxa belonging to 12 orders of macroinvertebrates were recorded in the studied wetlands. Hemiptera was the most diverse order having 10 taxa whereas Megaloptera, Oligocheta, Lepidoptera and Trombidiformes were recorded with single taxon. The Palaemonidae and Atyidae belonging to Decapod comprised $69.62 \%$ and $61.61 \%$, respectively of the individuals in the non-invaded wetlands, but were missing in abundant coverage wetlands (Figure 3). The invaded wetlands with abundant invasive species (A, $>75 \%$ coverage) had $36.47 \%$ and $46.56 \%$
Coleopterain the winter and spring seasons, respectively while there were less than $5 \%$ of these individuals in the non-invaded ones.

The Notonectidae, Corixidae and Gerridae belonging to Hemiptera were the most abundant taxa in the non-invaded wetlands, and their occurrences were low in the invaded wetlands. The Planorbidae, Viviparidae and Ampullaridae individuals belonging to Mollusca increased with the increased coverage of invasive plants, but the Lymnaeidae individuals did not change with increased coverage of invasive species.

Abundance of Ephemeroptera was high in the wetlands with frequent coverage (F, 25-50\%), but decreased in the ones with abundant coverage (A, $>75 \%$ ). The taxa belonging to Megaloptera, Trombidiformes, Oligocheta and Lepidoptera were recorded in very few numbers, and mostly found in the wetlands with intermediate invasive species coverage. The richness and abundance of Odonatataxa increased with the increased coverage of invasive species. The diversity of macroinvertebrate was observed high in the 
wetland with common (C, 50-75\%) and abundant (A, $>75 \%$ ) coverages of invasive species in both the seasons (Figure 4).

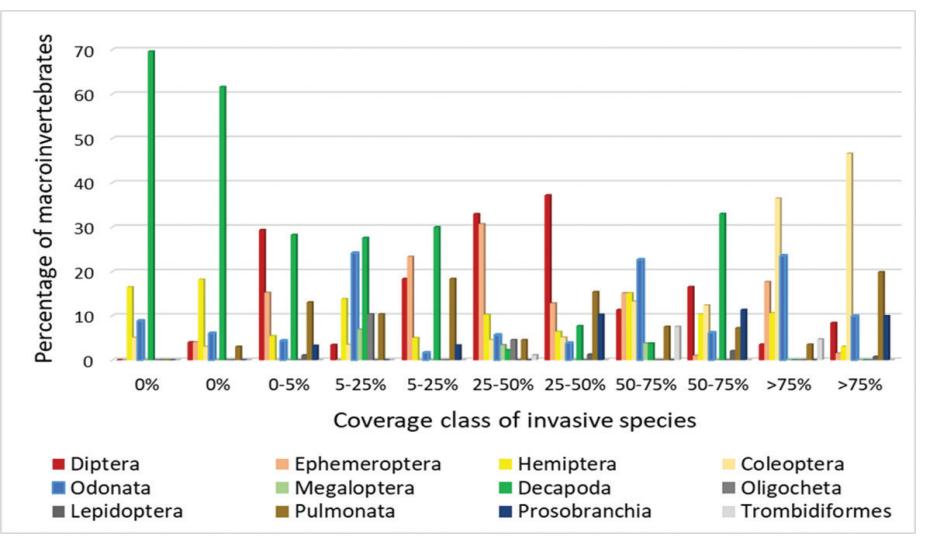

Fishes
In total, 22 fish species belonging to 5 order and 12 families were documented in the studied wetlands. Most of them were from Cypriniformes order and Cyprinidae family; altogether 12 different species represented the Cyprinidae family followed by the order Perciformes, Ambassidae family. The fish diversity index was high in the occasional coverage class ' $\mathrm{C}$ ' $(50-$ $75 \%$ ), followed by the non-invaded category and the frequent coverage class ' $\mathrm{F}$ ' $(25-50 \%$, Figure 5). The diversity increased with the increased invasive species coverage up to $25 \%$,

Fig. 3: Macroinvertebrate composition across the invasive species coverage classes in winter (January, 2018) and spring (May, 2018) seasons

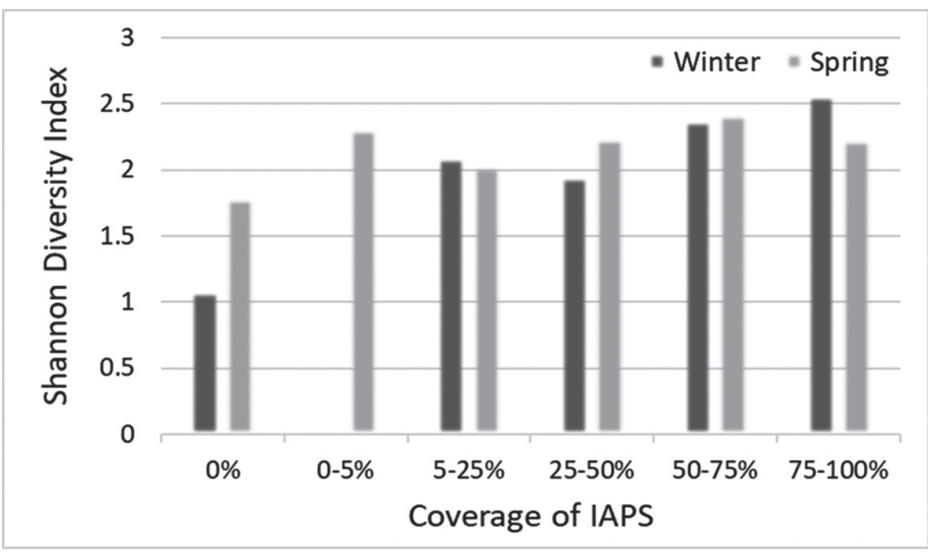
and then decreased with the further increase in the invasive species coverage.

The maximum number of fish species were recorded in the non-invaded wetlands while the least number of fish species recorded in the occasional coverage class ' $\mathrm{O}$ ' $(5-25 \%)$ in the winter season, but the lowest species richness was observed in the common coverage class ' $\mathrm{C}$ ' (50-75\%) in the spring season. The species richness was low in the winter season than in the spring season. The fish diversity was lowest in the common coverage class ' $\mathrm{C}$ ' $(50-75 \%)$.
Fig. 4: Macroinvertebrate diversity across the coverage classes of IAPS in winter (January, 2018) and spring (May, 2018) seasons

There was no significant difference in Shannon diversity index between the seasons i.e., winter and spring (Mann-Whitney U-test, $\mathrm{p}>0.05$ ). The analysis of similarities revealed that there was no significant difference in Shannon Diversity Index across the invasion coverage classes ( $>0.05$ ). The Sorensen's Similarity Index revealed 24\%, $44 \%, 48 \%$, and $43 \%$ similarities within the same coverage class when divided into only four coverage classes of $0-25 \%, 25-50 \%, 50-75 \%$ and $>75 \%$, respectively during the winter season. It was observed that $33.33 \%, 11.00 \%, 58.82 \%, 57.14 \%$, $32.34 \%$, and $43.24 \%$ taxa were overlapped within the non-invaded, rare ' $\mathrm{R}$ ', frequent ' $\mathrm{F}$ ', occasional 'O', common ' $\mathrm{C}$ ', and abundant 'A' coverage classes, respectively in the spring season.

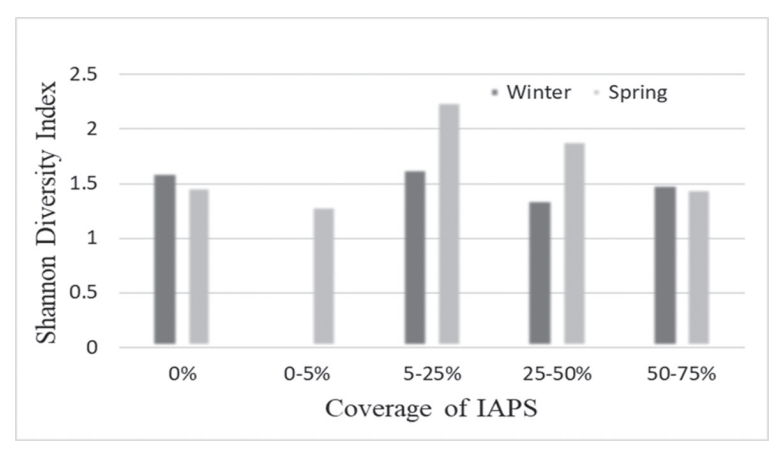

Fig. 5: Comparison between fish diversity across the coverage

\section{Of IAPS during winter and spring seasons}

There was no significant difference in the Shannon Diversity Index, species richness and species evenness when compared between the winter and spring seasons (Mann-Whitney U-test, $\mathrm{p}>0.05$ ). 
The analysis of similarities showed no significant difference across the invasion coverage classes $(\mathrm{p}>0.05)$. The Sorensen's Similarity Index showed $53 \%, 85 \%$, and $40 \%$ similarity within the same coverage class during the winter season, when divided into three coverage classes of $0-25 \%, 25-$ $50 \%$, and $50-75 \%$ based on the equal interval of percentage up to $75 \%$. Low similarity was observed in the spring season as compared to the winter season within the same coverage class. In totality, $71 \%, 33 \%, 40 \%, 50 \%$ and $40 \%$ species overlapped within the non-invaded, rare ' $\mathrm{R}$ ', frequent ' $\mathrm{F}$ ', occasional ' $\mathrm{O}$ ', and common ' $\mathrm{C}$ ' coverage classes, respectively.

\section{Discussion}

Many wetlands in the Koshi Tappu were found to be invaded with invasive macrophytes. This shows that the non-invaded wetlands have high probability of invasion, if appropriate measures are not considered on time. All the invaded wetlands were dominated by E. crassipes which falls in the list of 100 worst invasive species in aquatic system (Lowe et al., 2000) followed by $I$. carnea, P. stratiotes, and A. philoxeroides.

\section{Water quality parameters}

The weak relationship between the water temperature and increased invasive species coverage could be due to the barrier in heat exchange between the atmosphere and water surfaces as the macrophytes form the mat (Mironga et al., 2012). The spring season is decaying season, hence the heat generated from decay process is high, particularly in the wetlands with abundant coverage of macrophytes (Attionu, 1976). In the winter season, the water temperature was low in the wetlands with abundant coverage, because the mat of the macrophytes might have prevented the sunlight and heat exchange between the atmosphere and water surface. The increased coverage of the invasive species led to low $\mathrm{pH}$ (though not significant) which might be because of poor oxygenation and presence of carbonic and bicarbonic acids. The findings were similar to those of Mironga et al. (2012).

The seasonal variation in dissolved oxygen and free carbon dioxide are consistent with the results observed in other studies (Ndimele, 2012; Attionu, 1976; Gopal, 1987). The changes might be due to the decay of the dead plants and blockage of sunlight hindering photosynthesis and mixing of wind by the dense mat of the invasive species. The high alkalinity may be due to the presence of carbonates and bicarbonates in water. The natural carbon dioxide combines with water to form carbonic acid which is further dissociated into hydrogen and bicarbonate ions, hence alkalinity significantly increased in the winter season, corroborating with the findings of Svobodová (1993).

Many other studies showed that nutrient concentration such as nitrogen, potassium, phosphorus decreased with the increase in the coverage of macrophytes as macrophytes uptake nutrients for their growth (Maharjan \& Ming, 2012; Mironga et al., 2012; Ndimele, 2012; Nguyen et al., 2015). The uptake of nutrients decrease the nutrient concentration in water and again release into water during decomposition of macrophytes. Therefore, the nutrient concentrations did not vary in both the seasons in the invaded wetlands, corroborating with the findings of Tachamo-Shah et al. (unpublished) and Petr (2000). The low concentration of nitrate, phosphate and potassium in the spring season as compared to the winter season in this study might be due to the fact that the uptake of nutrient efficiency is high in warm season, long sunny days and flowering period (Penfound \& Earle, 1948).

The Koshi Tappu Wetlands with increased coverage of invasive species had lower concentration of chlorophyll-a, which might be due to the fact that invasive species stabilize water current, prevent sunlight for photosynthesis, and hence primary productivity become slow (Nguyen et al., 2015). However, the detritus loading during the decomposition of invasive species leads to increase in chlorophyll-a concentration (Gallardo et al., 2016), it could be the reason of high concentration of chlorophyll-a recorded in the abundant coverage class ' $\mathrm{A}$ ' ( $>75 \%$ coverage), hence this might be a cause of unclear relationship with the coverage of invasive species. The increased sunshine hour, decomposition of organic matters and algal growth may support increased concentration of chlorophyll-a in the spring season.

\section{Macroinvertebrate assemblages}

The wetlands were rich in aquatic macro invertebrate as depicted in the earlier study of 
Khatri et al. (2010). Hemiptera was the most diverse order in this study, similar to the findings of similar researches in the tropical lakes of Nepal, e.g. Shah et al. (2011), Tachamo-Shah et al. (unpublished). The Decapoda individuals were abundant in the non-invaded wetlands while absent in the invaded ones with abundant coverage class 'A' (>75\% coverage), because they need open space to swim in water surface. They occur in good water status with relatively high-oxygen level; nevertheless, these taxa can also survive at low-oxygen level by obtaining oxygen from the atmosphere during swimming in surface water (Kushlan and Kushlan, 1980). High Coleoptera abundance was recorded in the abundant coverage ' $\mathrm{A}$ ' ( $>75 \%$ coverage) wetlands as documented in the Beeshazari and the associated lakes (Tachamo-Shah et al., unpublished). Abundant macrophytes coverage provide suitable habitats to coleopteran to cling on stem and roots of the macrophytes and use leaves as food. Macrophytes also prevent macroinvertebrates to be preyed by higher level organisms like fishes (Petr, 2000). Therefore, high abundances of coleopteran are quite obvious in wetlands with large coverage of macrophytes. Hemiptera and Coleoptera (adults) can colonize in poor water quality as they do not solely depend on dissolved oxygen of water, but could trap oxygen from atmosphere. The low number of molluscan individuals in the Koshi wetlands contracted with the results for other parts of the world, (Pyron \& Brown, 2015).

Ephemeroptera order prefer littoral sections of wetlands where emergent plants exist. The species of this order are highly sensitive to toxic materials, inhabit in narrow temperature range and with low pH and dissolved oxygen (Alhejoj et al., 2014). In the Koshi Tappu, Ephemeroptera was abundant in the wetlands with $25-50 \%$ coverage of invasive species. The changes in the composition of the macroinvertebrates in the wetlands were due to the structural habitats provided by the macrophytes (Kouamé et al., 2011; Kovalenko et al., 2010; Schultz and Dibble, 2012; Stiers et al., 2011). The richness and abundance of odonates were high in the wetlands with high coverage of invasive species. As these odonates can survive at relatively low oxygen level and attach on the submerged macrophytes or roots of water hyacinth and water cabbage (Nesemann et al., 2011).

\section{Fishes}

Petr (2000) found that the wetlands with rare cover of macrophytes are suitable habitat for fish species for food and shelter, hence enhance diversity while increased coverage reduce the species diversity as it influences the foraging efficiency, space availability, and deplete oxygen concentration that hampers the fish diversity. These could be the reasons for decreased species diversity in the higher coverage of macrophytes in the Koshi Tappu Wetlands, similar to the findings of Gallardo et al. (2016).

The fish species richness was lower in the winter season than in the spring season, which may be influenced by breeding season as breeding generally favors the warm season (Pankhurst, 1997). The low richness of fish species in the invaded-wetlands with common and abundant coverage classes may be due to the poor water quality and lack of habitat suitability (Svobodová, 1993; Toft et al., 2003).

\section{Conclusion}

The study showed that the Koshi Tappu Wetlands were highly invaded by the invasive species, viz. E. crassipes, I. carnea, P. stratiotes and $A$. aphiloxeroides with about $67 \%$ of the wetlands being dominated by E. crassipes alone. The coverage of the invasive species was associated with the anthropogenic disturbances and land use pattern around the wetlands. The extensive coverage of invasive alien plant species adversely affected the water quality and fish communities, but supported the abundance of benthic macroinvertebrates in the wetlands. The findings of this study are expected to be useful to the concerned authorities for proper management of the Koshi Tappu Wetlands.

\section{References}

Alhejoj, I., Salameh, E. \& Bandel, K. (2014). Mayflies (Order Ephemeroptera): an effective indicator of water bodies conditions in Jordan. International Journal of Scientific Research in Environmental Sciences 2 (10): 361.

APHA. (1998). American Water Works Association and Water Environment Federation Standard methods for the examination of water and wastewater (pp. 39-42). American Public Health Association.

Attionu, R. H. (1976). Some effects of water 
lettuce (Pistia stratiotes, L.) on its habitat. Hydrobiologia 50 (3): 245-254.

Bassett, I., Paynter, Q., Hankin, R. \& Beggs, J. R. (2012). Characterising alligator weed (Alternanthera philoxeroides; Amaranthaceae) invasion at a northern New Zealand lake. New Zealand Journal of Ecology 216-222.

Carpenter, S. R., Cole, J. J., Pace, M. L., Batt, R., Brock, W. A, Cline, T., Coloso, J., Hodgson, J. R., Kitchell, J. F., Seekell, D. A., Smith, L. \& Weidel, B. (2011). Early warnings of regime shifts: a wholeecosystem experiment. Science 332 (6033): 1079-1082.

CBD. (1992). Convention on biological diversity. Paper presented at the Convention on Biological Diversity.

Chhetry, D. T. \& Pal, J. (2011). Diversity of Mammals in and around of Koshi Tappu Wildlife Reserve. Our Nature 8 (1): 254257.

DNPWC. (2009). Koshi Tappu Wildlife Reserve and Buffer Zone Management Plan (2009-2013). Government of Nepal, Ministry of Forests and Soil Conservation, Department of National Parks and Wildlife Conservation, Koshi Tappu Wildlife Reserve, Kathmandu.

DoFD. (2012). Annual Progress Report (2011). Directorate of Fisheries Development Kathmandu, Nepal.

Early, R., Bradley, B. A., Dukes, J. S., Lawler, J. J., Olden, J. D., Blumenthal, D. M., Gonzalez, P., Grosholz, E. D., Ibañez, I., Miller, L. P., Sorte, C. J. B. \& Tatem, A. J. (2016). Global threats from invasive alien species in the twenty-first century and national response capacities. Nature Communications 7 (12485) https://doi. org/10. 1038/ncomms 12485

Fatima, N., Rahman, M. M., Khan, M. A. \& $\mathrm{Fu}$, J. (2014). A review on Ipomoea carnea: pharmacology, toxicology and phytochemistry. Journal of Complementary and Integrative Medicine 11 (2): 55-62.
Gallardo, B., Clavero, M., Sánchez, M. I. \& Vilà, M. (2016). Global ecological impacts of invasive species in aquatic ecosystems. Global change biology 22 (1): 151-163.

Gopal, B. (1987). Water hyacinth. Elsevier Science Publishers.

Khatri, T. B., Shah, D. N., Tachamo-Shah,R. D. \& Mishra, N. (2010). Biodiversity of Koshi Tappu Wildlife Reserve: a post flood assessment. Journal of Wetlands Ecology 4: 69-82.

Kouamé, M. K., Dietoa, M. Y., Edia, E. O., Da Costa, S. K., Ouattara, A. \& Gourène, G. (2011). Macroinvertebrate communities associated with macrophyte habitats in a tropical man-made lake (Lake Taabo, Côte d'Ivoire). Knowledge and Management of Aquatic Ecosystems (2011) 400 03:18.

Kovalenko, K. E., Dibble, E. D. \& Slade, J. G. (2010). Community effects of invasive macro-phyte control: role of invasive plant abundance and habitat complexity. Journal of Applied Ecology 47 (2): 318-328.

Kushlan, J. A. \& Kushlan, M. S. (1980). Everglades alligator nests: nesting sites for marsh reptiles. Copeia 1980 (4): 930-932.

Lowe, S., Browne, M., Boudjelas, S. \& DePoorter, M. (2000). 100 of the world's worst invasive alien species: a selection from the global invasive species database. Vol. 12. Invasive Species Specialist Group Auckland.

Maharjan, R. B. S. \& Ming, C. L. (2012). The potential role of water hyacinth in wastewater treatment in Nepal. HydroNepal 10: $36-41$.

McGeoch, M. A., Butchart, S. H., Spear, D., Marais, E., Kleynhans, E. J., Symes, A. \& Hoffmann, M. (2010). Global indicators of biological invasion: species numbers, biodiversity impact and policy responses. Diversity and Distributions 16 (1): 95-108.

McNeely, J. (2001). Invasive species: a costly catastrophe for native biodiversity. Land Use and Water Resources Research1 (2): 
$1-10$.

MEA. (2005). Ecosystems and Human Wellbeing: Synthesis. Millinium Ecosystem Analysis.

Mironga, J. M., Mathooko, J. M. \& Onywere, S. M. (2012). Effect of water hyacinth infestation on the physicochemical characteristics of Lake Naivasha. International Journal of Humanities and Social Science 2 (7): 103113.

Mujere, N. (2016). Water Hyacinth: Characteristics, Problems, Control Options, and Beneficial Uses Impact of Water Pollution on Human Health and Environmental Sustainabilitypp. 343-361. IGI Global.

Ndimele, P. (2012). The Effects of Water Hyacinth (Eichhornia crassipes Solms) Infestation on the Physico-Chemistry, Nutrient and Heavy Metal Content of Badagry Creek and Ologe Lagoon, Lagos, Nigeria. Journal of Environmental Science and Technology 5 (2) : 128-136.

Nesemann, H., Sharma, S., Sharma, G., Khanal, S. N., Pradhan, B., Shah, D. N. \& Tachamo R. D. (2007). Aquatic Invertebrates of the Ganga River System (Mollusca, Annelida, Crustacea [in part]) vol. 1, Kathmandu, Nepal.

Nesemann, H., Tachamo-Shah, R. D. \& Shah, D. N. (2011). Key to the larval stages of common Odonata of Hindu Kush Himalaya, with short notes on habitats and ecology. Journal of threatened Taxa3 (9) : 2045-2060.

Nguyen, T. H. T., Boets, P., Lock, K., Ambarita, M. N. D., Forio, M. A. E., Sasha, P., Dominguez-Granda, L. E., Thi Hoang, T. H., Everaert, G. \& Goethalsa, P. L. M. (2015). Habitat suitability of the invasive water hyacinth and its relation to water quality and macroinvertebrate diversity in a tropical reservoir. Limnologica-Ecology and Management of Inland Waters 52 : $67-74$.

Pankhurst, N. (1997). Temperature effects on the reproductive performance of fish. Global warming: implications for freshwater and marine fish $61: 159$.

Penfound, W. T. \& Earle, T. T. (1948). The biology of the water hyacinth. Ecological Monographs 18 (4) : 447-472.

Petr, T. (2000). Interactions between fish and aquatic macrophytes in inland waters: a review. Food and Agriculture Organization.

Pimentel, D., Zuniga, R. \& Morrison, D. (2005). Update on the environmental and economic costs associated with alien-invasive species in the United States. Ecological Economics 52 (3): 273-288.

Pyron, M., \& Brown, K. M. (2015). Introduction to mollusca and the class Gastropoda. Thorp and Covich's Freshwater Invertebrates,Ecology and General Biology (Fourth Edition). (pp. 383-421). Elsevier.

Rejmánek, M. \& Richardson, D. M. (1996). What attributes make some plant species more invasive? Ecology 77 (6) : 1655-1661.

Savillo, I. T. (2009). Present status of Ramsar sites in Nepal. International Journal of Biodiversity and Conservation1 (5) : 146150.

Schultz, R. \& Dibble, E. (2012). Effects of invasive macrophytes on freshwater fish and macro-invertebrate communities: the role of invasive plant traits. Hydrobiologia $684: 1-14$.

Shah, D. N., Tachamo-Shah, R. D. \& Pradhan, B. K. (2011). Diversity and Community Assemblage of Littoral Zone Benthic Macroinvertebrate in Jagadishpur Reservoir. Nepal Journal of Science and Technology $12: 211-220$.

Shah, D. N., Sharma S. \& Tachamo-Shah, R. D. (2015). Rapid assessment of biodiversity, benthic macroinvertebrate. In Gopal, B. (eds) Guidelines for Rapid Assessment of Biodiversity and Ecosystem Services of Wetlands, Version 1. 0. Asia Pacific Network for Global Change Research (APN GCR), Kobe, Japan, and National 
Institute of Ecology, New Delhi. 134 pages.

Sharma, A. \& Bachheti, R. (2013). A review on Ipomoea carnea. International Journal of Pharmacy Biological Sciences 4 (4) : 363377.

Sharma, B., Rasul, G. \& Chettri, N. (2015). The economic value of wetland ecosystem services: evidence from the Koshi Tappu Wildlife Reserve, Nepal. Ecosystem Services 12 : 84-93.

Shrestha, B. B., Siwakoti, M. \& Ranjit, J. D. (2017). Status of Invasive Alien Plant Species in Nepal. In Proceedings of $2^{\text {nd }}$ National Workshop on CUAPGR, 2017.

Shrestha, T. K. (2008). Ichthyology of Nepal. Himalayan Ecosphere.

Siwakoti, M. (2012). Threats and opportunity of invasive alien plant species in wetland conservation of Nepal. Paper presented at the Proceedings of International Wetland Symposium.

Stiers, I., Crohain, N., Josens, G. \& Triest, L. (2011). Impact of three aquatic invasive species on native plants and macroinvertebrate in temperate ponds. Biological Invasions 13 (12): 2715-2726.

Sukhorukov, A. P. (2014). Erigeron annuus (Compositae)-a new record for the flora of Nepal. Newsletter of Himalayan Botany (49): 15-16.

Svobodová, Z. (1993). Water quality and fish health. Food and Agriculture Organization.

Tachamo-Shah, R. D., Shah D. N. \& Sada R. (unpublished). Ecological characteristics of Beeshazar and Associated Lakes, a Ramsar Site in Chitwan National Park.
Tachamo-Shah, R. D., Shah, D. N. \& Nesemann, H. (2011). Development of a macroinvertebrate-based Nepal Lake Biotic Index (NLBI): an applied method for assessing the ecological quality of lakes and reservoirs in Nepal, International Journal of Hydrology Science and Technology 1/2: 125-146.

Thapa, I. \& Dahal, B. (2009). Sustainable wetland management for wildlife and people at Koshi Tappu Wildlife Reserve. Banko Janakari 19 (3): 36-39.

Tiwari, S., Siwakoti, M., Adhikari, B. \& Subedi, K. (2005). An inventory and assessment of invasive alien plant species of Nepal. IUCN Nepal.

Toft, J. D., Simenstad, C. A., Cordell, J. R. \& Grimaldo, L. F. (2003). The effects of introduced water hyacinth on habitat structure, invertebrate assemblages, and fish diets. Estuaries26 (3): 746-758.

Zhu, Z., Zhou, C. \& Yang, J. (2015). Molecular phenotypes associated with anomalous stamen development in Alternanthera philoxeroides. Frontiers in plant science 6: 242.

Zimmels, Y., Kirzhner, F. \& Malkovskaja, A. (2006). Application of Eichhornia crassipes and Pistia stratiotes for treatment of urban sewage in Israel. Journal of Environmental Management81 (4): 420-428. 